\title{
Achromobacter denitrificans pneumonia in a kidney transplant recipient - dose-dependent decrease of phagocytic activity as a potential mechanism for everolimus pulmonary toxicity
}

\author{
JUSTYNA ELIZA GOEEBIEWSKA ${ }^{1}$, EWA BRYL ${ }^{2}$, AGNIESZKA DACA ${ }^{2}$, ANDRZEJ CHAMIENIA ${ }^{l}$, \\ DOMINIK ŚWIĘTON ${ }^{3}$, ALICJA DĘBSKA-ŚLIZIEN ${ }^{1}$
}

'Department of Nephrology, Transplantology and Internal Medicine, Medical University of Gdańsk, Poland

${ }^{2}$ Department of Pathology and Experimental Rheumatology, Medical University of Gdańsk, Poland

${ }^{3}$ Department of Radiology, Medical University of Gdańsk, Poland

\begin{abstract}
Mammalian target of rapamycin (mTOR) inhibitors inclusive regimens are associated with increased risk of pulmonary toxicity, but the underlying mechanism has not been elucidated so far.

We present the case of a 68-year-old man, after deceased-donor kidney transplantation (KTx), maintained on de novo everolimus (EVR) based immunosuppression, who developed Achromobacter denitrificans pneumonia 3 months after KTx. There was clinical improvement with antibiotic treatment, but without a radiological resolution. An additional reduction of the EVR dose resulted only in partial resolution of radiological abnormalities. We performed a functional analysis of peripheral blood neutrophils and monocytes. The ability of phagocytosis and oxidative burst generation against A. denitrificans and Escherichia coli was significantly decreased on EVR treatment as compared to the control healthy person, and significantly improved after 3 weeks of EVR absence. Additionally, these processes were significantly affected by increasing doses of EVR in vitro in the control healthy donor in a dose-dependent manner. EVR discontinuation, with no additional antibiotic treatment, resulted in complete recovery and resolution of pulmonary infiltrates.

Our findings suggest that dose-dependent impairment of neutrophil/monocyte phagocytic activity and oxidative burst generation might be a potential mechanism for EVR pulmonary toxicity.
\end{abstract}

Key words: kidney transplantation, Achromobacter denitrificans, mTOR inhibitors, everolimus, phagocytosis, oxidative burst generation.

(Cent Eur J Immunol 2021; 46 (3): 405-417)

\section{Introduction}

The mammalian target of rapamycin (mTOR) inhibitors sirolimus and everolimus (EVR) are immunosuppressive drugs commonly used in renal transplantation. mTOR inhibitors have antiangiogenic and antineoplastic properties, and therefore are associated with a lower risk of malignancy than other immunosuppressive agents. Reduced incidence of cytomegalovirus and BK virus (BKV) infections in kidney transplant (KTx) recipients receiving EVR were also reported [1,2]. Pulmonary adverse effects are relatively common in KTx recipients treated with mTOR inhibitors with a reported frequency of $2-11 \%$ and the onset of symptoms between 1 and 51 months after the initiation of therapy [3]. Several distinct types of pulmonary damage have been recognized, including lymphocytic interstitial pneumonitis, lymphocytic alveolitis, bronchiolitis obliterans with organizing pneumonia, focal pulmonary fibrosis, and even diffuse alveolar hemorrhage [3-5]. At the onset of this complication, patients with mTOR inhibitor-associated pneumonitis usually present with a cough and/or dyspnea and/or respiratory insufficiency, and sometimes with systemic symptoms such as fever and fatigue. Occasionally, only changes on high-resolution computed tomography (HRCT) scans are observed, with no accompanying clinical symptoms. The most common on HRCT 
Table 1. Trough levels of cyclosporine and everolimus after kidney transplantation

\begin{tabular}{lcc}
\hline $\begin{array}{l}\text { Time since kidney } \\
\text { transplantation } \\
\text { (weeks) }\end{array}$ & $\begin{array}{c}\text { Cyclosporine } \\
(\mathbf{n g} / \mathbf{m l})\end{array}$ & $\begin{array}{c}\text { Everolimus } \\
(\mathbf{n g} / \mathbf{m l})\end{array}$ \\
\hline 1 & 267.1 & 4.1 \\
\hline 2 & 193.1 & 2.9 \\
\hline 3 & 181.1 & 2.1 \\
\hline 4 & 240.6 & 3.3 \\
\hline 8 & 188.4 & 2.9 \\
\hline 12 & 150.0 & $7.1-$ EVR dose decreased \\
\hline 14 & 133.5 & $3.2-$ EVR dose decreased \\
\hline 15 & 127.9 & $2.1-$ EVR withheld \\
\hline 22 & 154.8 & - \\
\hline 25 & 168.6 & - \\
\hline
\end{tabular}

EVR-everolimus

scans are ground-glass opacities, inter-/intra-lobular septal linear thickening, or multifocal areas of parenchymal lung consolidation with a basilar predominance [3-5]. Also rare cases of opportunistic pulmonary infections, Pneumocystis jiroveci pneumonia and invasive pulmonary aspergillosis, mimicking typical noninfectious mTOR inhibitor-induced pulmonary adverse events, were reported in both EVR and temsirolimus treated patients [6-8].

Even though both the clinical symptoms and radiological signs have been well described, the etiopathogenic mechanism of mTOR-inhibitor-associated pulmonary toxicity is still unclear.

\section{Case report}

A 68-year-old man with end-stage renal disease of unknown etiology underwent a KTx from a 32-year old deceased female donor, who died of head trauma (cytomegalovirus D-/R+, Epstein-Barr virus D+/R+). He had a past history of type 2 diabetes, hypertension, coronary artery disease and squamous cell carcinoma of the tibial area resected 8 years before the KTx. His past medical history also included pulmonary tuberculosis. He had been maintained on haemodialysis for the preceding seven years. At the time of KTx he was in a good general condition. HLA mismatching was $0: 1: 0$ (A, B, DR), respectively. Anesthesia and surgery were uneventful, with good initial kidney perfusion. He underwent basiliximab induction therapy and commenced EVR, cyclosporine (CsA) and prednisone maintenance therapy. EVR was introduced because of the history of squamous cell carcinoma. CsA was chosen over tacrolimus in order to prevent significant deterioration of glycemic control in a patient with type 2 diabetes. The doses of EVR and cyclosporine were adjusted to maintain standard target trough levels. The chest
X-ray performed on the day of KTx showed no obvious abnormality. Three months later the patient presented with fever, progressive dyspnea, and a productive cough for two weeks. On general examination, the patient was conscious and well-oriented. He had a pulse rate of $108 / \mathrm{min}$, lood pressure of $100 / 60 \mathrm{mmHg}$, respiratory rate of 28 cycles/ min and there was evident cyanosis. Room air oxygen saturation was around $90 \%$. Other systemic examinations were normal. Admission chest radiography showed patchy infiltrates suggestive of bacterial pneumonia in the left inferior segments corresponding to crackles, rhonchi and wheezes on auscultation. His laboratory testing revealed a white blood cell (WBC) count of $15.8 \times 10^{9} / 1$, hemoglobin $11 \mathrm{~g} / \mathrm{dl}$, platelet count $216 \times 10^{9} / 1$, absolute neutrophil count $14.9 \times 10^{9} / 1$, absolute lymphocyte count $0.32 \times 10^{9} / 1$, and C-reactive protein (CRP) $281 \mathrm{mg} / \mathrm{l}$. Kidney function was stable with serum creatinine of $0.92 \mathrm{mg} / \mathrm{dl}$ and MDRD eGFR on admission $>60 \mathrm{ml} / \mathrm{min} / 1.73 \mathrm{~m}^{2}$. The EVR level was $7.1 \mathrm{ng} / \mathrm{ml}$ and cyclosporine level $150 \mathrm{ng} / \mathrm{ml}$ (Table 1).

He initially received amoxicillin/clavulanic acid. Bacterial cultures of blood and urine were negative. The symptoms improved, and fever resolved, with a decrease in both WBC and CRP levels over the next few days with empiric antibiotic treatment. There was clinical improvement, but without a radiological resolution. An HRCT scan (Fig. 1A) revealed a disseminated nodular pattern in both lungs, accompanied by peribronchial consolidations and lung parenchyma retraction dominating in the lower lobes. No pleural effusion was seen. Bronchoscopy was unremarkable. A transbronchial biopsy revealed mild nonspecific inflammation with areas of fibrosis in the bronchial walls. Bronchoalveolar lavage was sent for cell count, bacterial and viral culture, and fungal and acid-fast bacillus analysis. Both sputum and bronchoalveolar lavage cultures were positive for Achromobacter denitrificans. After a complete diagnostic workup including repeated bacterial and mycobacterial cultures, QuantiFERON1-TB Gold test, blood CMV-PCR, blood Aspergillus galactomannan and Candida mannan, immunofluorescent staining of bronchoalveolar fluid for Pneumocystis jiroveci, other pulmonary opportunistic infections were ruled out, and a diagnosis of A. denitrificans pneumonia and EVR pulmonary toxicity was made. A 17-day course of piperacillin/tazobactam chosen according to the susceptibility profile (Table 2), and a reduction of the EVR dose to the target trough levels of $2.8-3.2 \mathrm{ng} / \mathrm{ml}$ resulted only in partial resolution of radiological abnormalities confirmed by HRCT (Fig. 1B). After three weeks of antibiotic treatment EVR was withheld. EVR discontinuation with no additional antibiotic treatment resulted in complete recovery and a complete resolution of pulmonary infiltrates in an HRCT performed at a further 10-week follow-up (Fig. 1C). The immunosuppressive regimen on discharge was restricted to cyclosporine and glucocorticosteroids. 

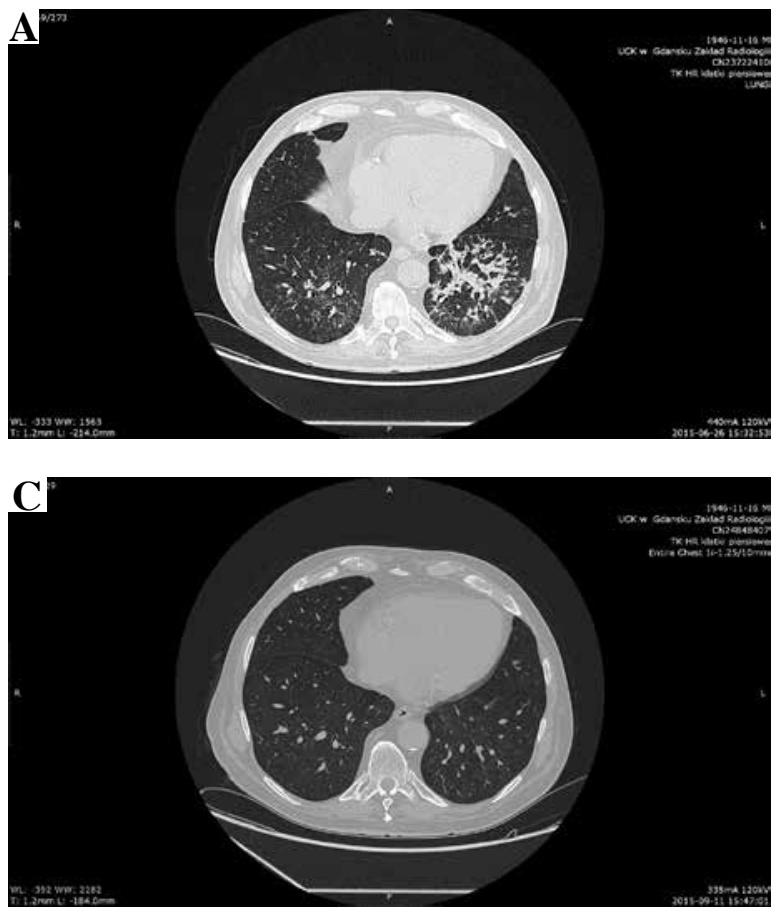

We performed a functional analysis of peripheral blood neutrophils and monocytes using Phagotest and Phagoburst tests (both Glycotope Biotechnology, Germany).

Phagotest measures the ability to perform phagocytosis, or specifically the ability of the phagocytes to take up the bacteria, by assessing the level of fluorescence emitted by phagocytes - both monocytes and neutrophils. The fluorescence comes from fluorescently stained bacteria engulfed by the phagocytes. Phagotest was performed in accordance with the manufacturer's protocol and with modifications. The original protocol involves the use of Escherichia coli stained with FITC (fluorescein) only (included in kit). Phagotest was also used for assessing the phagocytosis of $A$. denitrificans stained with CFDA (carboxyfluorescein diacetate succinimidyl ester). This method was established in our laboratory and described elsewhere [9]. The fluorescence emitted by phagocytes reflects the intensity of the engulfment of bacteria. Apart from using different bacteria, all stages of the manufacturer's manual were performed in the same manner for E. coli and A. denitrificans phagocytosis assessment. Phagoburst measures the ability of phagocytes to effectively kill the bacteria by the oxidative burst. The intensity of oxidative burst is estimated by assessing the conversion of non-fluorescent DHR123 (dihydrorhodamine 123) into green fluorescence-emitting R123 (rhodamine 123) in the presence of reactive oxidants. The higher the fluorescence is, the more intense is the oxidative burst. As in case of Phagotest, the assessment with $E$. coli (already in the manufacturer's kit) and $A$. denitrificans isolated from the patient's sputum and bronchoalveolar lavage was performed according to the

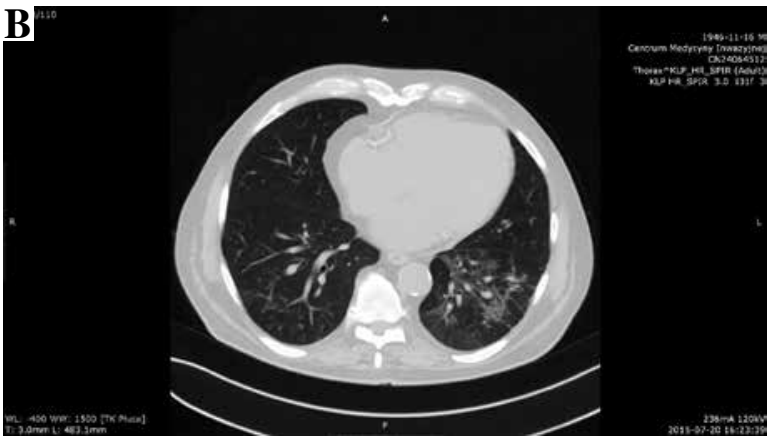

Fig. 1. A) Initial computed tomography (CT) of the lungs shows poorly defined bilateral patchy consolidations without pleural effusion, B) chest CT after 3-week antibiotic treatment and everolimus (EVR) dose reduction shows only partial resolution of bilateral patchy consolidations, C) CT performed 10 weeks after EVR discontinuation shows complete resolution of symptoms

manufacturer's protocol. The fluorescence intensity was assessed using a FACScan cytometer (BD, USA).

Flow cytometry techniques have been extensively used to evaluate phagocyte function. Both Phagotest and Phagoburst

Table 2. Antimicrobial susceptibility testing for Achromobacter denitrificans strains isolated from both sputum and broncho-alveolar lavage

\begin{tabular}{lcc}
\hline Antimicrobial & Sputum & $\begin{array}{c}\text { Broncho-alveolar } \\
\text { lavage }\end{array}$ \\
\hline Ampicillin & $\mathrm{R}$ & $\mathrm{R}$ \\
\hline Amoxicillin/clavulanic acid & $\mathrm{I}$ & $\mathrm{I}$ \\
\hline Piperacillin/tazobactam & $\mathrm{S}$ & $\mathrm{S}$ \\
\hline Cefazolin & $\mathrm{S}$ & $\mathrm{S}$ \\
\hline Cefuroxime sodium & $\mathrm{R}$ & $\mathrm{R}$ \\
\hline Cefotaxime & $\mathrm{R}$ & $\mathrm{R}$ \\
\hline Ceftriaxone & $\mathrm{R}$ & $\mathrm{R}$ \\
\hline Ceftazidime & $\mathrm{R}$ & $\mathrm{S}$ \\
\hline Cefepime & $\mathrm{I}$ & $\mathrm{S}$ \\
\hline Cefoperazone/sulbactam & $\mathrm{S}$ & $\mathrm{S}$ \\
\hline Ertapenem & $\mathrm{S}$ & $\mathrm{S}$ \\
\hline Imipenem & $\mathrm{S}$ & $\mathrm{S}$ \\
\hline Meropenem & $\mathrm{S}$ & $\mathrm{S}$ \\
\hline Amikacin & $\mathrm{S}$ & $\mathrm{S}$ \\
\hline Ciprofloxacin & $\mathrm{I}$ & $\mathrm{I}$ \\
\hline Trimethoprim/sulfamethoxazole & $\mathrm{R}$ & $\mathrm{R}$ \\
\hline S- susceptible, - intermediate, $R-r e s i s t a n t$ & \\
\hline
\end{tabular}

$S$-susceptible, $I$-intermediate, $R$-resistant 


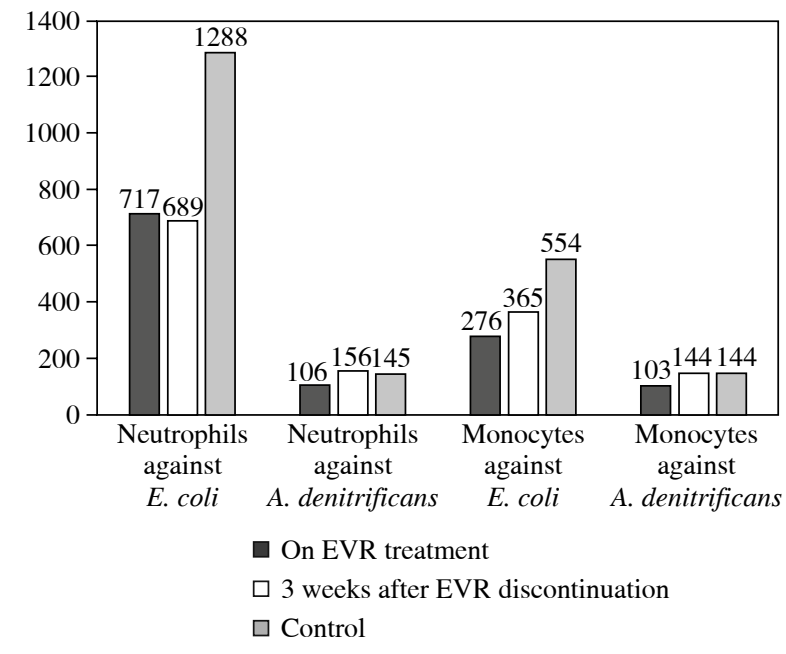

Fig. 2. Ex vivo phagocytic activity of neutrophils and monocytes against Escherichia coli and Achromobacter denitrificans measured by mean fluorescent intensity (MFI)

have been shown to be useful tests for the evaluation of phagocytosis and oxidative burst activity in different research contexts, providing repeatable and credible results [10-13].

The ex vivo phagocytic activity (Fig. 2) and intensity of oxidative burst (Fig. 3) measured by the mean fluorescent intensity (MFI) of neutrophils and monocytes against E. coli and A. denitrificans were assessed using patients' cells collected on EVR (2.8 ng/ml) and using patient cells collected 3 weeks after EVR discontinuation, and using cells from a healthy control.

The phagocytic activity against $A$. denitrificans and E. coli of patient neutrophils and monocytes collected during EVR treatment was notably lower compared to neu-

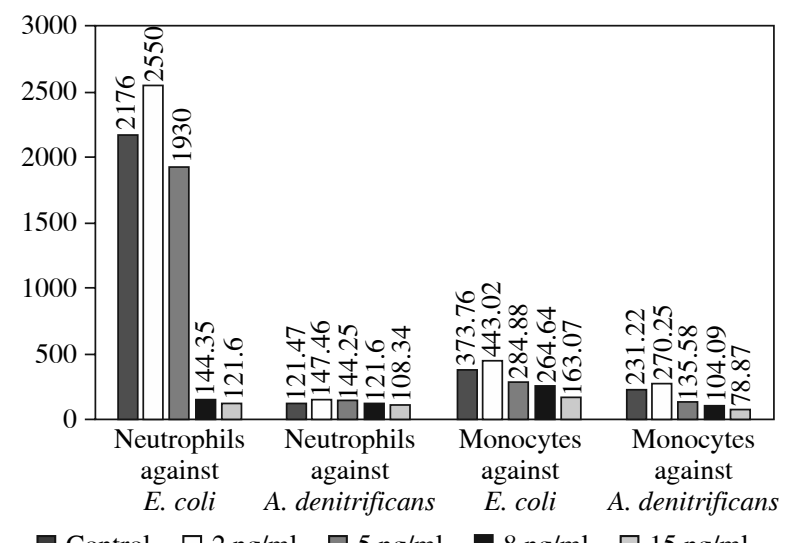

$\square$ Control $\square 2 \mathrm{ng} / \mathrm{ml} \quad \square 5 \mathrm{ng} / \mathrm{ml} \quad \square 8 \mathrm{ng} / \mathrm{ml} \quad \square 15 \mathrm{ng} / \mathrm{ml}$

Fig. 4. In vitro phagocytic activity against Escherichia coli and Achromobacter denitrificans of a healthy volunteer's neutrophils and monocytes exposed to different everolimus (EVR) concentrations measured by mean fluorescent intensity (MFI)

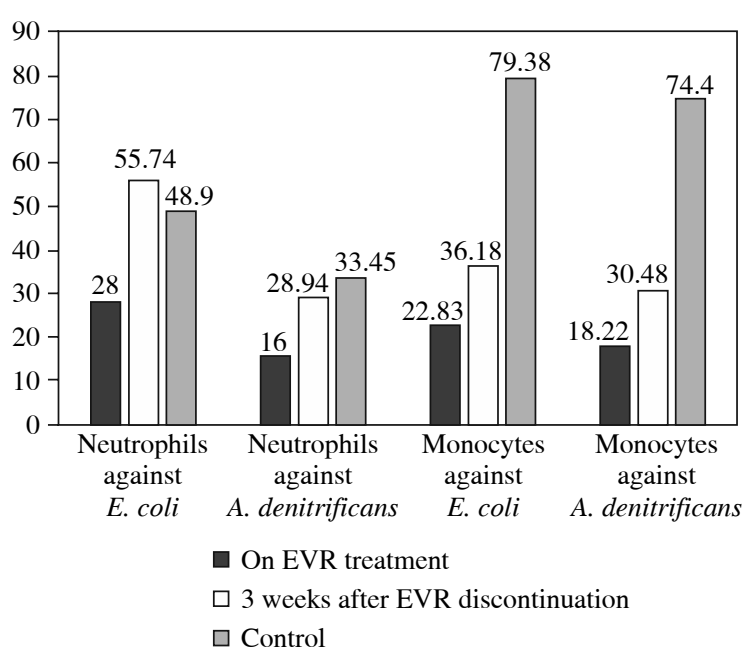

Fig. 3. Ex vivo intensity of oxidative burst of neutrophils and monocytes against Escherichia coli and Achromobacter denitrificans measured by mean fluorescent intensity (MFI)

trophils and monocytes from a healthy control, especially in the case of E. coli. The phagocytic activity of patient neutrophils and monocytes after 3 weeks of EVR absence was higher than patient cell activity in the presence of EVR. The phagocytic activity of patient cells off EVR against A. denitrificans was similar to the activity of healthy controls; however, the activity of patient cells off EVR against E. coli was still below the activity of control cells (Fig. 2).

The level of oxidative burst from neutrophils and monocytes, even more so, obtained from the patient on EVR treatment was significantly lower than the oxidative burst from the healthy control cells. After 3 weeks of EVR absence, the oxidative burst of patient neutrophils engulfing $E$. coli and A. denitrificans was restored to a level similar to the healthy control, even though the patient continued to receive prednisone and CsA. The level of oxidative burst carried out by patient monocytes was also improved with EVR absence, but still lower by half compared to monocytes of a healthy control (Fig. 3).

To confirm the aforementioned EVR properties we performed a similar assay in vitro using peripheral blood neutrophils and monocytes from a healthy donor. These cells were exposed to four different concentrations of EVR, ranging from 2 to $15 \mathrm{ng} / \mathrm{ml}(2 \mathrm{ng} / \mathrm{ml}, 5 \mathrm{ng} / \mathrm{ml}$, $8 \mathrm{ng} / \mathrm{ml}$ and $15 \mathrm{ng} / \mathrm{ml}$ ). The processes of phagocytosis and oxidative burst generation against both $A$. denitrificans and $E$. coli were again significantly affected by increasing doses of EVR in a dose-dependent manner (Figs. 4 and 5).

\section{Discussion and conclusions}

Few animal or in vitro studies have evaluated the pathogenesis of mTOR inhibitor-induced lung toxicities, 
and the underlying mechanisms remain to be determined. An immunological dose-independent origin is suggested, with three main mechanisms involved. First, mTOR inhibitors might expose cryptic antigens and induce an autoimmune response [14]. Second, a delayed-type hypersensitivity reaction is possible with an $\mathrm{mTOR}$ inhibitor as a hapten [15]. Third, pulmonary inflammation could be the consequence of cytokine production alterations caused by mTOR inhibitors. In vitro studies confirm that mTOR inhibitors stimulate the release of a number of proinflammatory cytokines such as interleukin (IL)-12, IL-23, tumor necrosis factor (TNF) and IL-1 $\beta$ while inhibiting the secretion of the anti-inflammatory cytokine IL-10 [15-17]. Additionally, a dose-related effect - and therefore directly toxic mTOR effect - has been suggested [14, 18].

Washino et al. found in an animal model that treatment with another mTOR inhibitor, temsirolimus, depleted alveolar macrophages in vivo, which, as the authors hypothesized, might lead to an accumulation of surfactant lipids, a condition seen in many respiratory pathologies. Temsirolimus also inhibited macrophage proliferation at lower drug concentrations, whereas it induced cell death in primary cultured alveolar macrophages at higher concentrations in vitro [19]. In another study by Wislez et al. [20] temsirolimus induced apoptosis of intraepithelial macrophages in alveolar epithelial neoplasia in K-rasLA1 mice. Several clinical case reports of EVR-induced lung injury also present macrophage depletion in BAL cell analyses $[21,22]$. Observations on the mTOR inhibitor influence on neutrophils and monocytes/macrophages are consistent with our results showing dose-dependent impairment of neutrophil/monocyte phagocytic activity and oxidative burst generation. Fernandez-Botran et al. reported that in patients suffering from community-acquired pneumonia, blood neutrophil functional responses (phagocytosis and phagocytosis-stimulated respiratory burst activity) were elevated as compared to healthy controls [23]. We observed that in our patient with pneumonia blood neutrophil and monocytes functional responses were significantly reduced after exposure to EVR, as demonstrated by ex vivo assays.

It is known that alveolar macrophages are major effector cells in initiating and orchestrating the respiratory immune response to infectious agents. Alveolar macrophage depletion and inadequate alveolar macrophage function may result in an increase in pulmonary surfactants, but also affect the resolution of tissue inflammation, leading to collateral damage. Macrophage-depleted mice showed both higher concentrations of intrapulmonary cytokines, with greater numbers of activated polymorphonuclear cells, and accumulation of apoptotic and secondary necrotic neutrophils when compared to control mice [24].

Achromobacter denitrificans is a gram-negative, mobile, strictly aerobic, ubiquitous, nonglucosefermenting, oxidase- and catalase-positive bacterium present in soil and water [25]. This bacterium only rarely causes human

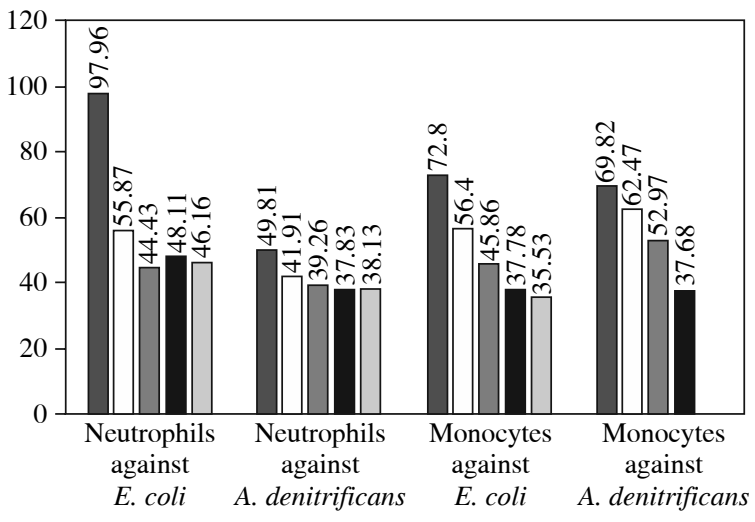

Control $\square 2 \mathrm{ng} / \mathrm{ml} \quad \square 5 \mathrm{ng} / \mathrm{ml} \quad \square 8 \mathrm{ng} / \mathrm{ml} \quad \square 15 \mathrm{ng} / \mathrm{ml}$

Fig. 5. In vitro intensity of oxidative burst against Escherichia coli and Achromobacter denitrificans of a healthy volunteer's neutrophils and monocytes exposed to different everolimus (EVR) concentrations measured by the mean fluorescent intensity (MFI)

infections. Most of the infections by Achromobacter are asymptomatic. The symptomatic infections usually occur in immunodeficient patients and include cases of bacteriemia, natural valve or prosthetic valve endocarditis, meningitis, pneumonia, peritonitis, conjunctivitis, osteomyelitis, intra-abdominal abscess, and prosthesis infections [26].

Therefore, the observed $A$. denitrificans pneumonia was probably a superimposed phenomenon resulting from the same, as in the case of mTOR-related pneumonitis and impaired function of neutrophils and monocytes/macrophages. Given the presented clinical scenario it is difficult to clearly distinguish between the relative contributions of infection and possible EVR toxicity. Other cases of opportunistic pulmonary infections, Pneumocystis jiroveci pneumonia and invasive pulmonary aspergillosis, mimicking typical pulmonary adverse noninfectious mTOR inhibitor-induced pneumonitis and cryptogenic organizing pneumonia, have been reported previously in both EVR and temsirolimus treated patients [6-8]. In all three cases the identification of opportunistic pathogens in both bronchoalveolar lavage and biopsy specimens was an unexpected finding. Pneumocystis jiroveci infection induced only mild chronic inflammation assessed by bronchoalveolar lavage fluid analysis, and the authors concluded that the paucity of inflammatory reaction could result from immunosuppression due to cancer recurrence or glucocorticosteroid treatment [6]. This could also reflect the impaired function of neutrophils and monocytes/macrophages.

In a large phase III clinical trial program of EVR the incidence of interstitial lung disease was $0.4 \%$. In three of the four heart Tx recipients the discontinuation of EVR resulted in interstitial lung disease improvement or resolution, while there was no improvement in a patient who continued to receive EVR. The outcome was fatal in the 
KTx recipient, in whom EVR therapy was continued and in the liver Tx recipient despite EVR discontinuation, probably due to a superimposed infection. After having analyzed the available literature, the authors concluded that prompt discontinuation of mTOR inhibitor therapy as soon as interstitial lung disease is diagnosed is crucial to ensure a favorable outcome [27].

Withdrawal of immunosuppression is a key component of treating infections in immunocompromised patients. However, the neutrophil and monocyte/macrophage function clearly improved after withdrawing EVR, even though the patient was still maintained on prednisolone and cyclosporine. The in vitro dose-dependent impairment of a healthy volunteer's neutrophil/monocyte functional responses also would suggest direct EVR toxicity. This is in agreement with a study by Solazzo et al., which reported a relationship of interstitial lung disease to EVR trough concentration $>9.03 \mathrm{ng} / \mathrm{ml}$ in a group of $500 \mathrm{KTx}$ recipients on an EVR and CsA combined protocol [28].

In conclusion, the present report is the first to suggest dose-dependent impairment of neutrophil/monocyte functional responses such as phagocytic activity and oxidative burst generation, as possible mechanisms of mTOR associated pulmonary toxicity. The phenomenon described provides one possible explanation; however, more rigorous investigation is needed to define the exact biological machinery associated with this clinical condition.

\section{Ethics approval and consent to participate}

Bioethics Committee of the Medical University of Gdańsk approval no. NKBBN/195/2018. One of the authors (A.D.) provided a blood sample as a healthy control after providing written informed consent. Written informed consent was obtained from the patient for publication of this case report and all accompanying images.

\section{Availability of data and materials}

All data containing relevant information to support the findings is included in the manuscript. There are no data sheets related to this case report.

\section{Funding}

This work was supported by the Polish Committee for Scientific Research via the Medical University of Gdansk (ST-4). The funder had no role in study design, data collection and analysis, decision to publish or preparation of the manuscript.

\section{Acknowledgements}

We sincerely thank all health care workers who contributed to management of this patient including the micro- biology and immunology teams, and all who helped us to publish the case report.

The authors declare no conflict of interest.

\section{References}

1. Tedesco-Silva H, Felipe C, Ferreira A, et al. (2015): Reduced incidence of cytomegalovirus infection in kidney transplant recipients receiving everolimus and reduced tacrolimus doses. Am J Transplant 15: 2655-2664.

2. Moscarelli L, Caroti L, Antognoli G, et al. (2013): Everolimus leads to a lower risk of BKV viremia than mycophenolic acid in de novo renal transplantation patients: a single-center experience. Clin Transplant 27: 546-554.

3. Zaza G, Tomei P, Ria P, et al. (2013): Systemic and nonrenal adverse effects occurring in renal transplant patients treated with mTOR inhibitors. Clin Dev Immunol 2013: 403280.

4. Champion L, Stern M, Israël-Biet D, et al. (2006): Brief communication: sirolimus-associated pneumonitis: 24 cases in renal transplant recipients. Ann Intern Med 144: 505-509.

5. Vandewiele B, Vandecasteele SJ, Vanwalleghem L, De Vriese AS (2010): Diffuse alveolar hemorrhage induced by everolimus. Chest 137: 456-459.

6. Tanaka Y, Saraya T, Kurai D, et al. (2014): Spontaneous resolution of Pneumocystis jirovecii pneumonia on high-resolution computed tomography in a patient with renal cell carcinoma. Am J Case Rep 15: 496-500.

7. Saito Y, Nagayama M, Miura Y, et al. (2013): A case of pneumocystis pneumonia associated with everolimus therapy for renal cell carcinoma. Jpn J Clin Oncol 43: 559-562.

8. Iijima Y, Fujioka N, Uchida Y, et al. (2018): Invasive pulmonary aspergillosis mimicking organizing pneumonia after mTOR inhibitor therapy: a case report. Int J Infect Dis 69: 75-77.

9. Jarzembowski T, Daca A, Witkowski JM, et al. (2015): The high PMNs phagocytosis resistance of enterococcal isolates from RTx patients. Biomed Res Int 2015: 432579.

10. Lehmann AK, Sornes S, Halstensen A (2000): Phagocytosis: measurement by flow cytometry. J Immunol Methods 243: 229-242.

11. Kampen AH, Tollersrud T, Larsen S, et al. (2004): Repeatability of flow cytometric and classical measurement of phagocytosis and respiratory burst in bovine polymorphonuclear leukocytes. Vet Immunol Immunopathol 97: 105-114.

12. Parment K, Zetterberg A, Ernerudh J, et al. (2007): Long-term immunosuppression in burned patients assessed by in vitro neutrophil oxidative burst (Phagoburst). Burns 33: 865-871.

13. Baëhl S, Garneau H, Le Page A, et al. (2015): Altered neutrophil functions in elderly patients during a 6-month follow-up period after a hip fracture. Exp Gerontol 65: 58-68.

14. Morelon E, Stern M, Israël-Biet D, et al. (2001): Characteristics of sirolimus-associated interstitial pneumonitis in renal transplant patients. Transplantation 72: 787-790.

15. Pham PT, Pham PC, Danovitch GM, et al. (2004): Sirolimus-associated pulmonary toxicity. Transplantation 77: 1215-1220.

16. Schmitz F, Heit A, Dreher S, et al. (2008): Mammalian target of rapamycin (mTOR) orchestrates the defense program of innate immune cells. Eur J Immunol 38: 2981-2992.

17. Säemann MD, Haidinger M, Hecking M, et al. (2009): The multifunctional role of mTOR in innate immunity: implications for transplant immunity. Am J Transplant 9: 2655-2661. 
18. Willemsen AE, Grutters JC, Gerritsen WR, et al. (2016): mTOR inhibitor-induced interstitial lung disease in cancer patients: Comprehensive review and a practical management algorithm. Int J Cancer 138: 2312-2321.

19. Washino S, Ando H, Ushijima K, et al. (2014): Temsirolimus induces surfactant lipid accumulation and lung inflammation in mice. Am J Physiol Lung Cell Mol Physiol 306: L1117-1128.

20. Wislez M, Spencer ML, Izzo JG, et al. (2005): Inhibition of mammalian target of rapamycin reverses alveolar epithelial neoplasia induced by oncogenic K-ras. Cancer Res 65: 32263235.

21. Saito Y, Kunugi S, Suzuki Y, et al. (2013): Granuloma forming interstitial pneumonia occurring one year after the start of everolimus therapy. Int Med 52: 263-267.

22. Sakamoto S, Kikuchi N, Ichikawa A, et al. (2013): Everolimus-induced pneumonitis after drug-eluting stent implantation: a case report. Cardiovasc Intervent Radiol 36: 1151-1154.

23. Fernandez-Botran R, Uriarte SM, Arnold FW, et al. (2014): Contrasting inflammatory responses in severe and non-severe community-acquired pneumonia. Inflammation 37: 1158-1166.

24. Knapp S, Leemans JC, Florquin S, et al. (2003): Alveolar macrophages have a protective antiinflammatory role during murine pneumococcal pneumonia. Am J Respir Crit Care Med 167: 171-179.

25. Coenye T, Vancanneyt M, Cnockaert MC, et al. (2003): Kerstersia gyiorum gen. nov., sp. nov., a novel Alcaligenes faecalis-like organism isolated from human clinical samples, and reclassification of Alcaligenes denitrificans Rüger and Tan 1983 as Achromobacter denitrificans comb. nov. Int J Syst Evol Microbiol 53: 1825-1831.

26. Sgrelli A, Mencacci A, Fiorio M, et al. (2012): Achromobacter denitrificans renal abscess. New Microbiol 35: 245-247.

27. Lopez P, Kohler S, Dimri S (2014): Interstitial lung disease associated with mTOR inhibitors in solid organ transplant recipients: results from a large phase III clinical trial program of everolimus and review of the literature. J Transplant 2014: 305931.

28. Solazzo A, Botta C, Nava F, et al. (2016): Interstitial lung disease after kidney transplantation and the role of everolimus. Transplant Proc 48: 349-351. 


\section{INDEX OF PAPERS}

\section{Volume 46, Issue 1-3, 2021}

Bajoriuniene I, Musteikiene G, Ramonaite A, Sitkauskiene B: DiHS/DRESS syndrome induced by second-line treatment for tuberculosis and Epstein-Barr virus 401

Bańos-Hernández CJ, Bucala R, Hernández-Bello J, Navarro-Zarza JE, Villanueva-Pérez MA, GodínezRubí M, Parra-Rojas I, Vázquez-Villamar M, PereiraSuárez AL, Muńoz Valle JF: Expression of macrophage migration inhibitory factor and its receptor CD74 in systemic sclerosis 375

Billert H, Bednarek E, Kusza K, Ponichter M, Kurpisz M: Effect of acute isooxic hypercapnia on oxidative activity of systemic neutrophils in endotoxemic rabbits 47

Bogucka-Fedorczuk A, Czyż A, Szuba A, Machnicki MM, Pępek M, Płoski R, Stokłosa T, Wróbel T: Co-occurrence of unclassified myeloproliferative neoplasm and giant cell arteritis in a patient treated with allogeneic hematopoietic stem cell transplantation: a case report and literature review 121

Brzozowska M, Mokrzycka N, Porebski G: Alpha-gal syndrome: the first report in Poland 398

Ding J, Zhang X, Xue J, Fang L, Ban C, Song B, Wu L: CircNPM1 strengthens Adriamycin resistance in acute myeloid leukemia by mediating the miR-345-5p/FZD5 pathway 162

Džopalić T, Božić-Nedeljković B, Jurišić V: The role of vitamin $A$ and vitamin $D$ in modulation of the immune response with a focus on innate lymphoid cells 264

Fasshauer M, Schuermann G, Gebert N, von Bernuth H, Goldacker S, Krueger R, Manzey P, Notheis G, Ritterbusch H, Schauer U, Schulze I, Umlauf V, Widmann S, Baumann U: A structured patient empowerment programme for primary immunodeficiency significantly improves general and health-related quality of life 244

Ferreira S, Masi J, Giménez V, Carpinelli MM, Laterza O, Hermoso M, Ortiz-Villalba J, Chamorro ME, Langjahr P: Effect of gluten-free diet on levels of soluble CD14 and lipopolysaccharide-binding protein in adult patients with celiac disease 225

Fijałkowska M, Kowalski M, Koziej M, Antoszewski B: Elevated serum levels of cathelicidin and $\beta$-defensin 2 are associated with basal cell carcinoma 360
Gao F, Guo Y: Efficacy and specificity of different methods for human neutrophil extracellular trap isolation and handling 384

Glushkov A, Polenok E, Gordeeva L, Mun S, Kostyanko M, Antonov A, Verzhbitskaya N, Vafin I: Immuno-hormonal network in postmenopausal women: disturbance in breast cancer patients 68

Gołębiewska JE, Bryl E, Daca A, Chamienia A, Świętoń D, Dębska-Ślizień A Achromobacter denitrificans pneumoniain a kidney transplant recipient - dose-dependent decrease of phagocytic activity as a potential mechanism for everolimus pulmonary toxicity 405

Gowin E, Bąbol-Pokora K, Januszkiewicz-Lewandowska D: Mutation in the proline-serine-threonine phosphatase-interacting protein 1 ( $P S T P I P 1)$ gene in a patient with acute lymphoblastic leukemia 270

Hyla-Klekot L, Wolny A, Janas-Kozik M, Koszutski T: Anorexia nervosa and juvenile lupus erythematosus in a 16-year-old female patient - common disease origin or random coincidence? 127

Jałowska MD, Gornowicz-Porowska J, Seraszek-Jaros A, Bowszyc-Dmochowska M, Kaczmarek E, Dmochowski M: Conceptualization and validation of an innovative direct immunofluorescence technique utilizing fluorescein conjugate against $\mathrm{IgG}+\mathrm{IgG} 4$ for routinely diagnosing autoimmune bullous dermatoses 183

Kaźmierczyk-Winciorek M, Nędzi-Góra M, Słotwińska SM: The immunomodulating role of probiotics in the prevention and treatment of oral diseases 99

Kolesova O, Kramica K, Kolesovs A, Eglite J: Expression of ORAI1 and STIM1 genes in blood of patients with pulmonary tuberculosis 275

Kołtan S, Kołtan A, Soszyńska K, Matiakowska K, Morgut-Klimkowska M, Grześk E, Grześk G, Dąbrowska A, Urbańczyk A, Konieczek J, Styczyński J, Haus O, Wysocki M: Killer-cell immunoglobulin-like receptor genotype and haplotype combinations in children treated for acute lymphoblastic leukemia 210

Kosałka-Węgiel J, Milewski M, Siwiec A, Strach M, Ochrem B, Korkosz M: Severe hypereosinophilic syndrome successfully treated with a monoclonal antibody against interleukin 5 receptor $\alpha$ - benralizumab 395 
Kostic M, Dzopalic T, Marjanovic G, Urosevic I, Milosevic I: Immunomodulatory effects of galectin-1 in patients with chronic lymphocytic leukemia 54

Kuźmicka W, Moskalik A, Manda-Handzlik A, Demkow U, Wachowska M, Ciepiela O: Influence of iron- and zinc-chelating agents on neutrophil extracellular trap formation 135

Lu Y, Wang G, Li C: Expression of peripheral monocytic programmed death ligand-1 in severe sepsis combined with HBV-related cirrhosis. A pilot observational study 217

Marcinkiewicz J, Witkowski JM, Olszanecki R: The dual role of the immune system in the course of COVID-19. The fatal impact of the aging immune system 1

Mizerska-Wasiak M, Gajewski Ł, Cichoń-Kawa K, Siejko A, Małdyk J, Spława-Neyman A, Zachwieja J, Firszt-Adamczyk A, Stankiewicz R, Drożyńska-Duklas M, Żurowska A, Bieniaś B, Sikora P, Pukajło-Marczyk A, Zwolińska D, Szczepańska M, Pawlak-Bratkowska M, Tkaczyk M, Stelmaszczyk-Emmel A, Pańczyk-Tomaszewska M: Relationship between Gd-IgA1 and TNFR1 in IgA nephropathy and IgA vasculitis nephritis in children - multicenter study 199

Nassif MA: Urine and serum interleukin 35 as potential biomarkers of lupus nephritis 351

Nędzi-Góra M, Górska R, Górski B: The utility of gingival crevicular fluid matrix metalloproteinase- 8 provides site-specific diagnostic value for periodontal grading 236

Pan J, Wang X, Cang X, Jiang Y, Tang R: Hsa_ circ_0010957 knockdown attenuates lipopolysaccharide-induced HK2 cell injury by regulating the miR-12245p/IRAK1 axis 314

Pańczyk-Tomaszewska M, Skrzypczyk P, Mroczkowski K, Leszczyńska B, Mizerska-Wasiak M: Treatment of idiopathic nephrotic syndrome with two steroid dosing regimens - one-year observational study 344

Pawlik-Gwozdecka D, Górska-Ponikowska M, Adamkiewicz-Drożyńska E, Niedźwiecki M: Serum heat shock protein 90 as a future predictive biomarker in childhood acute lymphoblastic leukemia 63

Pérez-Soto E, Oros-Pantoja R, Fernández-Martínez E, Carbonell-Campos JM, Sánchez Monroy V: Seminal pro-inflammatory cytokines and $\mathrm{pH}$ are affected by Chlamydia infection in asymptomatic patients with teratozoospermia 76
Pierzyna-Świtała M, Sędek Ł, Kulis J, Mazur B, Muszyńska-Rosłan K, Kołtan A, Woszczyk M, Niedźwiecki M, Mizia-Malarz A, Karolczyk G, Lejman M, Trelińska J, Badowska W, Derwich K, Ociepa T, Malinowska I, Kazanowska B, Kowalczyk J, Szczepański T: Multicolor flow cytometry immunophenotyping and characterization of aneuploidy in pediatric B-cell precursor acute lymphoblastic leukemia 365

Rupp MC, Bergmann CB, Jung S, Bock M, Biberthaler P, Heimann L, Hanschen M: The posttraumatic response of CD4+ regulatory $\mathrm{T}$ cells is modulated by direct cell-cell contact via CD40L- and P-selectin-dependent pathways 283

Samelska K, Zaleska-Żmijewska A, Bałan B, Grąbczewski A, Szaflik JP, Kubiak AJ, Skopiński P: Immunological and molecular basics of the primary open angle glaucoma pathomechanism 111

Shoji S, Uchida K, Inoue G, Takata K, Mukai M, Aikawa J, Iwase D, Takano S, Sekiguchi H, Takaso M: Increase in CD5L expression in the synovial membrane of knee osteoarthritis patients with obesity 231

Skopiński P, Radomska-Leśniewska DM, Izdebska J, Kamińska A, Kupis M, Kubiak AJ, Samelska K: New perspectives of immunomodulation and neuroprotection in glaucoma 105

Skrzypczyk P, Zacharzewska A, Szyszka M, Ofiara A, Pańczyk-Tomaszewska M: Arterial stiffness in children with primary hypertension is related to subclinical inflammation 336

Słotwiński R, Lech G, Słotwińska SM: Molecular aspects of pancreatic cancer: focus on reprogrammed metabolism in a nutrient-deficient environment and potential therapeutic targets 258

Słotwiński R, Słotwińska SM: Pancreatic cancer and adaptive metabolism in a nutrient-deficient environment 388

Stelmasiak M, Bałan BJ, Mikaszewska-Sokolewicz M, Niewiński G, Kosałka K, Szczepanowska E, Słotwiński R: The relationship between the degree of malnutrition and changes in selected parameters of the immune response in critically ill patients 82

Sun M, Wu J, Liu W: Profiling changes in microRNAs of immature dendritic cells differentiated from human monocytes 10 
Švajger U, Rožman PJ: Mixed cultures of allogeneic dendritic cells are phenotypically and functionally stable - a potential for primary cell-based "off the shelf" product generation 152

Volokha A, Bondarenko A, Chernyshova L, Hilfanova A, Stepanovskiy Y, Boyarchuk O, Kostyuchenko L: Impact of the J Project on progress of primary immunodeficiency care in Ukraine 250

Wang B, Wang Y, Xu K, Zeng Z, Xu Z, Yue D, Li T, Luo J, Liu J, Yuan J: Resveratrol alleviates sepsis-induced acute kidney injury by deactivating the lncRNA MALAT1/ MiR-205 axis 295

Wielińska J, Tarassi K, Iwaszko M, Kościńska K, Wysoczańska B, Mole E, Kitsiou V, Świerkot J, Kolossa K, Kouniaki D, Athanassiades T, Tsirogianni A, Bogunia-Kubik K: Shared epitope and polymorphism of MICA and $N K G 2 D$ encoding genes in Greek and Polish patients with rheumatoid arthritis 92

Xu W, Li S, Chang X: E2F2 stimulates CCR4 expression and activates synovial fibroblast-like cells in rheumatoid arthritis 27

Xue X, Liu Q, Xu W, Yuan J, Zhou H, Zou X, Han S, Meng X, Wang X: Imbalanced Th17/Treg in peripheral blood of adult patients with immunoglobulin A vasculitis nephritis 191
Yu Y, Zhu C, Yu N, Yang L: Tim-1 alleviates lupus nephritis-induced podocyte injury via regulating autophagy 305

Zdanowicz K, Daniluk U, Jewsiejenko E, Krasnodębska M, Motkowski R, Lebensztejn DM: Diagnosis of autoimmune neutropenia in a 10-month-old boy - a case report 118

Zhang B, Zhang Y, Li R, Li Y, Yan W: Knockdown of circular RNA hsa_circ_0003204 inhibits oxidative stress and apoptosis through the miR-330-5p/Nod2 axis to ameliorate endothelial cell injury induced by low-density lipoprotein 140

Zhang X, Zhang J, Li F, Luo Y, Jiang S: PDCD4-mediated downregulation of Listeria monocytogenes burden in macrophages 38

Zhang Y, Xie L, Lu W, Lv J, Li Y, Shao Y, Sun J: LncRNA MIAT enhances systemic lupus erythematosus by upregulating CFHR5 expression via miR-222 degradation 17

Zhong J, Cheng B, Yang L, Li G, Yuan Y, Luo G, Shu Z, Jiang H: LncRNA ZEB1-AS1 knockdown alleviates oxidative low-density lipoprotein-induced endothelial cell injury via the miR-590-5p/HDAC9 axis 325 


\section{INDEX OF AUTHORS}

Volume 46, Issue 1-3, 2021

Adamkiewicz-Drożyńska E 63

Aikawa J 231

Antonov A 68

Antoszewski B 360

Athanassiades T 92

Badowska W 365

Bajoriuniene I 401

Bałan BJ 82, 111

Ban C 162

Bańos-Hernández CJ 375

Baumann U 244

Bąbol-Pokora K 270

Bednarek E 47

Bergmann CB 283

Biberthaler P 283

Bieniaś B 199

Billert H 47

Bock M 283

Bogucka-Fedorczuk A 121

Bogunia-Kubik 92

Bondarenko A 250

Bowszyc-Dmochowska M 183

Boyarchuk O 250

Božić-Nedeljković B 264

Bryl E 405

Brzozowska M 398

Bucala R 375

Cang X 314

Carbonell-Campos JM 76

Carpinelli MM 225

Chamienia A 405

Chamorro ME 225

Chang X 27

Cheng B 325

Chernyshova L 250

Cichoń-Kawa K 199

Ciepiela O 135

Czyż A 121

Daca A 405

Daniluk U 118

Dąbrowska A 210

Demkow U 135

Derwich K 365

Dębska-Ślizień A 405

Ding J 162

Dmochowski M 183

Drożyńska-Duklas M 199

Džopalić T 54, 264

Eglite J 275

Fang L 162
Fasshauer M 244

Fernández-Martínez E 76

Ferreira S 225

Fijałkowska M 360

Firszt-Adamczyk A 199

Gajewski Ł 199

Gao F 384

Gebert N 244

Giménez V 225

Glushkov A 68

Godínez-Rubí M 375

Goldacker S 244

Gołębiewska JE 405

Gordeeva L 68

Gornowicz-Porowska J 183

Gowin E 270

Górska R 236

Górska-Ponikowska M 63

Górski B 236

Grąbczewski A 111

Grześk E 210

Grześk G 210

Guo Y 384

Han S 191

Hanschen M 283

Haus O 210

Heimann L 283

Hermoso M 225

Hernández-Bello J 375

Hilfanova A 250

Hyla-Klekot L 127

Inoue G 231

Iwase D 231

Iwaszko M 92

Izdebska J 105

Jałowska MD 183

Janas-Kozik M 127

Januszkiewicz-Lewandowska D 270

Jewsiejenko E 118

Jiang H 325

Jiang S 38

Jiang Y 314

Jung S 283

Jurišić V 264

Kaczmarek E 183

Kamińska A 105

Karolczyk G 365

Kazanowska B 365

Kaźmierczyk-Winciorek M 99

Kitsiou V 92 
Kolesova O 275

Kolesovs A 275

Kolossa K 92

Kołtan A 210, 365

Kołtan S 210

Konieczek J 210

Korkosz M 395

Kosałka K 82

Kosałka-Węgiel J 395

Kostic M 54

Kostyanko M 68

Kostyuchenko L 250

Koszutski T 127

Kościńska K 92

Kouniaki D 92

Kowalczyk J 365

Kowalski M 360

Koziej M 360

Kramica K 275

Krasnodębska M 118

Krueger R 244

Kubiak AJ 105, 111

Kulis J 365

Kupis M 105

Kurpisz M 47

Kusza K 47

Kuźmicka W 135

Langjahr P 225

Laterza O 225

Lebensztejn DM 118

Lech G 258

Lejman M 365

Leszczyńska B 344

Li C 217

Li F 38

Li G 325

Li R 140

Li S 27

Li T 295

Li Y 17, 140

Liu J 295

Liu Q 191

Liu W 10

Lu W 17

Lu Y 217

Luo G 325

Luo J 295

Luo Y 38

Lv J 17

Machnicki MM 121

Malinowska I 365

Małdyk J 199

Manda-Handzlik A 135

Manzey P 244

Marcinkiewicz J 1
Marjanovic G 54

Masi J 225

Matiakowska K 210

Mazur B 365

Meng X 191

Mikaszewska-Sokolewicz M 82

Milewski M 395

Milosevic I 54

Mizerska-Wasiak M 199, 344

Mizia-Malarz A 365

Mokrzycka N 398

Mole E 92

Morgut-Klimkowska M 210

Moskalik A 135

Motkowski 118

Mroczkowski K 344

Mukai M 231

Mun S 68

Muńoz Valle JF 375

Musteikiene G 401

Muszyńska-Rosłan K 365

Nassif MA 351

Navarro-Zarza JE 375

Nędzi-Góra M 99, 236

Niedźwiecki M 63, 365

Niewiński G 82

Notheis G 244

Ochrem B 395

Ociepa T 365

Ofiara A 336

Olszanecki R 1

Oros-Pantoja R 76

Ortiz-Villalba J 225

Pan J 314

Pańczyk-Tomaszewska M 199, 336, 344

Parra-Rojas I 375

Pawlak-Bratkowska M 199

Pawlik-Gwozdecka D 63

Pereira-Suárez AL 375

Pérez-Soto E 76

Pępek M 121

Pierzyna-Świtała M 365

Płoski R 121

Polenok E 68

Ponichter M 47

Porebski G 398

Pukajło-Marczyk A 199

Radomska-Leśniewska DM 105

Ramonaite A 401

Ritterbusch H 244

Rožman PJ 152

Rupp MC 283

Samelska K 105, 111

Sánchez Monroy V 76

Schauer U 244 
Schuermann G 244

Schulze I 244

Sekiguchi H 231

Seraszek-Jaros A 183

Sędek Ł 365

Shao Y 17

Shoji S 231

Shu Z 325

Siejko A 199

Sikora P 199

Sitkauskiene B 401

Siwiec A 395

Skopiński P 105, 111

Skrzypczyk P 336, 344

Słotwińska SM 99, 258, 388

Słotwiński R 82, 258, 388

Song B 162

Soszyńska K 210

Spława-Neyman A 199

Stankiewicz R 199

Stelmasiak M 82

Stelmaszczyk-Emmel A 199

Stepanovskiy Y 250

Stokłosa T 121

Strach M 395

Styczyński J 210

Sun J 17

Sun M 10

Švajger U 152

Szaflik JP 111

Szczepanowska E 82

Szczepańska M 199

Szczepański T 365

Szuba A 121

Szyszka M 336

Świerkot J 92

Świętoń D 405

Takano S 231

Takaso M 231

Takata K 231

Tang R 314

Tarassi K 92

Tkaczyk M 199

Trelińska J 365

Tsirogianni A 92

Uchida K 231

Umlauf V 244

Urbańczyk A 210

Urosevic I 54

Vafin I 68

Vázquez-Villamar M 375

Verzhbitskaya N 68

Villanueva-Pérez MA 375

Volokha A 250

von Bernuth H 244
Wachowska M 135

Wang B 295

Wang G 217

Wang X[iaoqin] 191

Wang X[iujie] 314

Wang Y 295

Widmann S 244

Wielińska J 92

Witkowski JM 1

Wolny A 127

Woszczyk M 365

Wróbel T 121

Wu J 10

Wu L 162

Wysocki M 210

Wysoczańska B 92

Xie L 17

Xu K 295

Xu W[anju] 27

Xu W[encheng] 191

Xu Z 295

Xue J 162

Xue X 191

Yan W 140

Yang L[ijuan] 305

Yang L[i] 325

Yu N 305

Yu Y 305

Yuan J[un] 191

Yuan J[iemin] 295

Yuan Y 325

Yue D 295

Zacharzewska A 336

Zachwieja J 199

Zaleska-Żmijewska A 111

Zdanowicz K 118

Zeng Z 295

Zhang B 140

Zhang J 38

Zhang X[iaochun] 162

Zhang X[ingju] 38

Zhang Y[ufan] 140

Zhang Y[ali] 17

Zhong J 325

Zhou H 191

Zhu C 305

Zou X 191

Zwolińska D 199

Żurowska A 199 